\title{
A novel synthesis of 1-aryl-3-piperidone derivatives
}

\author{
Yinan Zhang and Richard B. Silverman * \\ Department of Chemistry, Chemistry of Life Processes Institute, Center for Molecular Innovation \\ and Drug Design, Northwestern University, Evanston, Illinois 60208-3113 USA
}

\begin{abstract}
A novel method to construct the 1-aryl-3-piperidone scaffold is described here. Starting from 3,5dichloroaniline, a seven-step synthesis, without the use of protecting groups, generates the desired 3-piperidone ring in an overall yield of 30\% through a key Morita-Baylis-Hillman reaction and ring-closing metathesis, providing easy access to diverse and useful heterocycles.
\end{abstract}

\section{Keywords}

3-Piperidone; Synthesis; Morita-Baylis-Hillman; Ring-closing metathesis; Heterocycles

The piperidine ring is a ubiquitous structure present in many natural alkaloids ${ }^{1}$ and drug candidates ${ }^{2}$ therefore, its synthesis attracts much interest from organic chemists (Figure 1 ). Of the piperidine derivatives, 3-piperidone is an important intermediate because of its easy conversion to other functional groups using various methods for the construction of bioactive heterocycles. For example, the transformation of a 4-carboethoxy-3-piperidone to pyrimidinone RO3203546, a selective a-1 antagonist, ${ }^{3}$ and the rearrangement of a 2methyl-3-piperidone to a 2 -acetylpyrrolidine ${ }^{4}$ proceed from 3-piperidone intermediates.

A typical procedure to 3-piperidones employs an intramolecular Claisen condensation of two branched esters of a tertiary amine to form a cyclic $\beta$-ketoester, followed by decarboxylation. ${ }^{5}$ However, the extra deprotection step, as well as the moderate to low yield in the Claisen condensation, limits its application. Here we report a novel route to construct 1-aryl-3-piperidone-4-carboxylate analogues without the use of protecting groups.

As part of an ongoing project in our group to discover a therapeutic for amyotrophic lateral sclerosis (ALS), ${ }^{6}$ the synthesis of the 3-piperidone, 1-(3,5-dichlorophenyl)-4carboethoxy-3-piperidone (6), was a high priority. Initially we tried diethyl carbonate and Mander's reagent, ${ }^{7}$ which was successful in our synthesis of the isomeric 1-aryl-4piperidone-3-carboxylate $\mathbf{2}$, but those reagents gave no $\beta$-ketoester from 3-piperidone 5 (Scheme 1). A Dieckmann condensation of diester $\mathbf{3}$ was shown to be an effective alternative route, but that reaction also failed when applied to 7. Possibly, the intramolecular enolate attack does not occur because the planar aniline structure (7) reduces the flexibility

(c) 2012 Elsevier Ltd. All rights reserved.

"To whom correspondence should be addressed at the Department of Chemistry, Northwestern University, 2145 Sheridan Road, Evanston, IL 60208-3113. Phone: 1-847-491-5653. Fax: 1-847-491-7713. Agman@chem.northwestern.edu.

Supplementary data

Supplementary data associated with this article can be found in the online version at XXX.

Publisher's Disclaimer: This is a PDF file of an unedited manuscript that has been accepted for publication. As a service to our customers we are providing this early version of the manuscript. The manuscript will undergo copyediting, typesetting, and review of the resulting proof before it is published in its final citable form. Please note that during the production process errors may be discovered which could affect the content, and all legal disclaimers that apply to the journal pertain. 
of the ester chain and causes a loss of its ability to condense with the other ester. Several other attempts, including the use of a strong lithium base, intramolecular Claisen condensation between the corresponding Weinreb amide and an ester, and a Buchwald amination of the corresponding phenyl bromide and 3-piperidone, also failed.

Since two possible bond-breaking positions around the $\beta$-ketoester moiety $(\mathbf{6}$, a and $b$, Figure 2) were fruitless, our focus shifted to position c. Given the wide utilization of Grubbs catalysts to mediate ring closing metathesis reactions,${ }^{8}$ we decided to replace the single bond at position $\mathrm{c}$ with a double bond. The double bond might isomerize from position $\mathrm{c}$ to $\mathrm{b}$, which would provide the $\beta$-ketoester from the isomeric allylic alcohol in one step. Retrosynthetically, $\mathbf{6}$ could be derived from $\mathbf{8}$, which could come from another key synthon 9 through a Morita-Baylis-Hillman (MBH) nucleophilic addition, ${ }^{9}$ and $\mathbf{9}$ could be made from commercially available $\mathbf{1 0}$.

The selective reactions of ethyl bromoacetate and allyl bromide with the aniline were performed under standard conditions (Scheme 2) in good yields.

Subsequent conversion to 8 was achieved via DIBAL reduction and then MBH nucleophilic attack of acrylate mediated by DABCO. Standard conditions for ring-closing metathesis with 5\% Grubbs II catalyst produced cyclic allyl alcohol 12 in near quantitative yields; the product yield decreased if the loading amount of Grubbs catalyst was reduced (see Supplementary Data). With $\mathbf{1 2}$ in hand, several redox isomerization reactions of allyl alcohols to carbonyl compounds were explored, including $\mathrm{Pd} / \mathrm{C}, \mathrm{Ru}\left(\mathrm{PPh}_{3}\right)_{2} \mathrm{Cl}_{2},{ }^{10}$ and $\mathrm{Cp} * \mathrm{Ru}\left(\mathrm{CH}_{3} \mathrm{CN}\right)_{3} \mathrm{PF}_{6} .{ }^{11}$ However, no desired isomeric product was observed. Therefore, 12 was converted to $\mathbf{6}$ by hydrogenolysis of the double bond followed by Dess-Martin periodinane oxidation of the alcohol in good yields, giving 6 in an overall yield of $30 \%$ for the seven steps. Compound $\mathbf{6}$ was readily converted to our desired pyrazolone analogue $\mathbf{1 3}$ with hydrazine.

The 3-piperidinone analogue (6) is a useful intermediate for the synthesis of a variety of heterocycles, such as pyrimidinones, ${ }^{12}$ quinuclidinones, ${ }^{13}$ cyclohexanediamines, ${ }^{14}$ and benzomorphans. ${ }^{15}$ Furthermore, medium size ring derivatives, such as azepanone and azocanone analogues, could be attainable from homoallylic or $\gamma$-propionate anilines using standard RCM conditions. ${ }^{16}$

In conclusion, a novel synthesis of 1-aryl-3-piperidone-4-carboxylates has been accomplished without the need for protecting groups. This method should be highly applicable to the synthesis of a variety of diverse heterocyclic compounds.

\section{Supplementary Material}

Refer to Web version on PubMed Central for supplementary material.

\section{Acknowledgments}

We thank the National Institutes of Health (grant 1R43NS057849), the ALS Association (TREAT program), and the Department of Defense (AL093052), for their generous support of this research project.

\section{References}

1. O’Hagan D. Nat Prod Rep. 2000; 17:435-446. [PubMed: 11072891]

2. a) Hu LY, Ryder TR, Rafferty MF, Feng MR, Lotarski SM, Rock DM, Sinz M, Stoehr Sally J, Taylor Charles P, Weber ML, Bowersox SS, Miljanich GP, Millerman E, Wang YX, Szoke BG. J Med Chem. 1999; 42:4239-4249. [PubMed: 10514294] b) Becker, CK.; Caroon, JM.; Melville, 
CR.; Padilla, F.; Pfister, JR.; Zhang, X. WO 02/053558. 2002. p. A1c) Large CH, Bison S, Sartori I, Read KD, Gozzi A, Quarta D, Antolini M, Hollands E. J Pharmacol Exp Ther. 2011; 338:100-113. [PubMed: 21487071]

3. Connolly TJ, Matchett M, Sarma K. Org Proc Res Dev. 2005; 9:80-87.

4. Zhao S, Jeon HB, Nadkarni DV, Sayre LM. Tetrahedron. 2006; 62:6361-6369.

5. Scalone M, Waldmeier P. Org Proc Res Dev. 2003; 7:418-425.

6. a) Chen T, Benmohamed R, Kim J, Smith K, Amante D, Morimoto RI, Ferrante RJ, Kirsch D, Silverman RB. J Med Chem. 2012; 55:515-527. [PubMed: 22191331] b) Zhang Y, Silverman RBJ. Org Chem. 2012; 77:3462-3467.

7. Mander LN, Sethi SP. Tetrahedron Lett. 1983; 24:5425-5428.

8. For review and recent examples of RCM application in heterocyclic synthesis: Vougioukalakis GC, Grubbs RH. Chem Rev. 2010; 110:1746-1783. [PubMed: 20000700] Dondas HA, Clique B, Cetinkaya B, Grigg R, Kilner C, Morris J, Sridharan V. Tetrahedron. 2005; 61:1065210666.Polshettiwar V, Varma RS. J Org Chem. 2008; 73:7417-7419. [PubMed: 18722404] Sattely ES, Alexander Cortez G, Moebius DC, Schrock RR, Hoveyda AH. J Am Chem Soc. 2005; 127:8526-8533. [PubMed: 15941288]

9. a) Basavaiah D, Reddy BS, Badsara SS. Chem Rev. 2010; 110:5447-5674. [PubMed: 20735052] b) Masson G, Housseman C, Zhu J. Angew Chem Int Ed. 2007; 46:4614-4628.

10. Basavaiah D, Muthukumaran K. Syn Comm. 1999; 29:713-719.

11. a) Fagan PJ, Ward MD, Clabrese JC. J Am Chem Soc. 1989; 111:1698-1719.b) Bouziane A, Carboni B, Bruneau C, Carreaux F, Renaud J. Tetrahedron. 2008; 64:11745-11750.

12. Connolly TJ, Matchett M, Sarma K. Org Proc Res Dev. 2005; 9:80-87.

13. Da Silva Goes AJ, Cave C, d'Angelo J. Tetraheron Lett. 1998; 39:1939-1940.

14. Wang JX, Zhang YB, Liu ML, Wang B, Chai Y, Li SJ, Guo H-Y. Eur J Med Chem. 2011; 46:2421-2426. [PubMed: 21481984]

15. Khartulyari AS, Maier ME. Eur J Org Chem. 2007:317-324.

16. Chattopadhyay SK, Karmakar S, Biswas T, Majumdar KC, Rahaman H, Roy B. Tetrahedron. 2007; 63:3919-3952. 


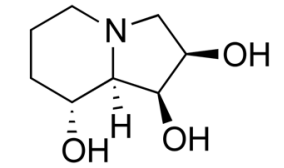

Swainsonine<smiles>C=CC1=CN2CC[C@H]([C@H](O)c3ccnc4ccc(OC)cc34)C[C@H]1C2</smiles>

Quinine<smiles>c1ccc(C2(N3CCCCC3)CCCCC2)cc1</smiles>

Phencyclidine<smiles>Fc1ccc(C2CCNC[C@@H]2OCc2ccc3c(c2)OCO3)cc1</smiles>

Figure 1.

Examples of piperidine-containing alkaloids and drugs 

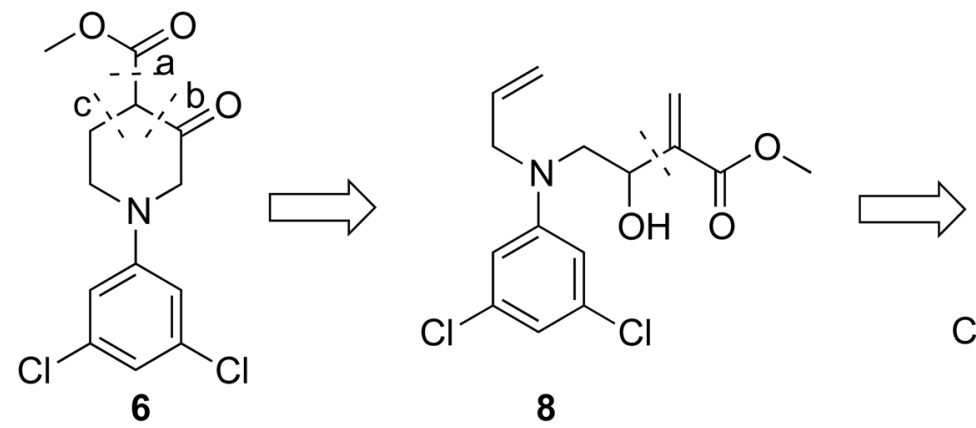<smiles>C=CCN(CC=O)c1cc(Cl)cc(Cl)c1</smiles><smiles>Nc1cc(Cl)cc(Cl)c1</smiles>

Figure 2.

Retrosynthetic analysis of 3-piperidone analog. 
<smiles>CCOC(=O)C1=C(O)CCN(c2cc(Cl)cc(Cl)c2)C1</smiles><smiles>CCOC(=O)CCCN(CC(=O)OCC)Cc1ccccc1</smiles><smiles>O=C1CCCN(c2cc(Cl)cc(Cl)c2)C1</smiles>

5<smiles>CC(C)(C)C(C)(C)C</smiles><smiles>CCOC(=O)C1=C(O)CN(c2cc(Cl)cc(Cl)c2)CC1</smiles>

6<smiles>CCOC(=O)CCCN(CCC(=O)OCC)c1cc(Cl)cc(Cl)c1</smiles>

Scheme 1.

Reagents and conditions: (a) $(\mathrm{EtO})_{2} \mathrm{CO}$ or $\mathrm{CNCOOMe}, \mathrm{NaH}, \mathrm{MeOH}$, toluene, $80{ }^{\circ} \mathrm{C}, 3 \mathrm{~h}$, 24\%; (b) NaH, toluene, reflux, 4 h, $52 \% .^{3}$ 
<smiles>C=CCN(CC(O)C(=C)C(C)C)c1cc(Cl)cc(Cl)c1</smiles><smiles>CC(=O)C1=CCN(c2cc(Cl)cc(Cl)c2)CC1O</smiles><smiles>CC(=O)C1=C(O)CN(c2cc(Cl)cc(Cl)c2)CC1</smiles><smiles>O=c1[nH][nH]c2c1CCN(c1cc(Cl)cc(Cl)c1)C2</smiles>

Scheme 2.

Reagents and conditions: (a) $\mathrm{BrCH}_{2} \mathrm{COOEt}$, DIPEA, $90{ }^{\circ} \mathrm{C}, 24 \mathrm{~h}, 88 \%$; (b) $\mathrm{K}_{2} \mathrm{CO}_{3}$, NaI, allyl bromide, $\mathrm{CH}_{3} \mathrm{CN}$, reflux, 2 days, $83 \%$; (c) DIBAL, DCM, $-78{ }^{\circ} \mathrm{C}, 1 \mathrm{~h}, 86 \%$; (d) DABCO, methyl acrylate, room temp, 3 days, $71 \%$; (e) 5 mol\% Grubbs II, DCM, reflux, 5 h, $96 \%$; (f) $5 \mathrm{~mol} \% \mathrm{Pd} / \mathrm{C}, \mathrm{MeOH}$, reflux, $16 \mathrm{~h}$; (g) $5 \mathrm{~mol} \% \mathrm{Ru}\left(\mathrm{PPh}_{3}\right)_{2} \mathrm{Cl}_{2}$ toluene, $\mathrm{K}_{2} \mathrm{CO}_{3}$, $100{ }^{\circ} \mathrm{C}, 16 \mathrm{~h}$; (h) $\mathrm{Cp} * \mathrm{Ru}\left(\mathrm{CH}_{3} \mathrm{CN}\right)_{3} \mathrm{PF}_{6}, \mathrm{~K}_{2} \mathrm{CO}_{3}, \mathrm{CH}_{3} \mathrm{CN}, 80^{\circ} \mathrm{C}, 1 \mathrm{~h}$; (i) $\mathrm{Pd} / \mathrm{C}$, EtOAc, $1 \mathrm{~atm}$ $\mathrm{H}_{2}$, room temp, $16 \mathrm{~h}$; (j) Dess-Martin periodinane, DCM, room temp, $1 \mathrm{~h}, 70 \%$ for two steps; (k) $\mathrm{NH}_{2} \mathrm{NH}_{2}$, EtOH, room temp, 16 h, $74 \%$. 